\title{
小続命湯に関する一考察 (I)
}

一小続 命 湯治 験—

寺澤 捷年 ${ }^{* 1}$ ，土佐 寛順 ${ }^{* 1}$ ，檜山 孝幸 ${ }^{* 1}$ ，今田屋 章*2

\section{A Study of Xiao-xu-ming-tang (1)}

-Clinical Report on Xiao-xu-ming-tang-

\section{Katsutoshi TERASAWA ${ }^{* 1}$, Hiroyori TOSA*1, Yukitaka HIYAMA* and Akira IMADAYA*2}

\section{苗}

小続命湯は備急千金要方1) 巻八・諸風第二に収載 されている方剂である。その主治するところは「治 卒中風欲死。身躰緩急。口目不正。舌強不能語。奄 奄忽忽。神情闖乱。諸風服之皆験不令人虚方」と記 されている。

「方」は麻黄・防已・人参・黄芩・桂心・甘草・

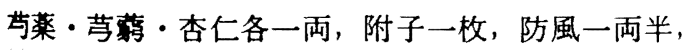
生姜五両である。

千金方では「諸風第二」に先立って「論雑風状第 一」があり，風に侵された諸種の病態を詳細に記し ているが，これによれば本方は脳卒中のみならず， 諸々の風に侵された病症に広く応用しらることが諒 解される。

また本方は「諸風第二」の冒頭の方剤として収載 されており，千金方の著者・係思邀は本方をきわめ て重要な方剤として位置つけていると考えてょい。 本方はいわゆる脳卒中の要方として古来, 頻用さ れた形跡があるが233)，近年その治験報告に接するこ とは少なく，われわれの調查しえた限りでは, 昭和 初期から今日までの間, 大塚敬節著『漢方治療の実 祭』4) の小続命湯の解説として, 手指麻疸 - 歩行障 害の一症例と, 脳血管障害の一症例が記されている のみである。
近年，われわれは，千金方の記す「諸風服之皆験」 に注目し本方を諸種の病態に試みたところ，本方が 応用範囲の相当に広い方剂であることを改めて知ら された。

ここでは第一報として代表的な治験例 5 例を報告 する。な打用いた生薬の分量等は表 1 によった。

表 1 小続命湯の使用生薬と用量

\begin{tabular}{|c|c|c|c|c|}
\hline 麻 & & 黄 & $2.0 \mathrm{~g}$ & 中 国 (大連) \\
\hline 漢 & 防 & 已 & $2.0 \mathrm{~g}$ & 四 国 \\
\hline 人 & & 参 & $1.0 \mathrm{~g}$ & 韓 国 \\
\hline 黄 & & 芩 & $2.0 \mathrm{~g}$ & 中 国 (河北) \\
\hline 桂 & & 枝 & $2.0 \mathrm{~g}$ & 中 国（広西） \\
\hline 甘 & & 草 & $1.0 \mathrm{~g}$ & 中 国 (西北) \\
\hline 苟 & & 薬 & $2.0 \mathrm{~g}$ & 奈 良 \\
\hline 川 & & 䒮 & $2.0 \mathrm{~g}$ & 北海道 \\
\hline 杏 & & 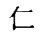 & $3.5 \mathrm{~g}$ & 中 国 (天津) \\
\hline 炮 & 附 & 子 & & 中 国 (四川) \\
\hline 真 & 防 & 風 & $2.0 \mathrm{~g}$ & 中 国 \\
\hline 生 & & 姜 & $1.0 \mathrm{~g}$ & 中 国(雲南) \\
\hline
\end{tabular}

\section{症例報告}

症例 1：43才, 男性, 会社役員 左顔面神経麻舫を主訴に 初診。

現病歴：同年—，左の肩凝りを自覚。 朝, 鼻汁, 後頭部痛, 身体異和感を伴う感冒様

\footnotetext{
*1医，富山医科薬科大学和漢診療部，富山， *2医，富山県立中央病院内科（和漢診療），富山。 ${ }^{* 1}$ M. D. , Department ot Sino-Japanese Medicine, Toyama Medical \& Pharmaceutical University Hospital, Toyama. *2M. D. , Department ot Internal Medicine (Sino-Japanese Medicine), Toyama Prefectural Central Hospital, Toyama.
} 
症状が出現。同時に沾柿を口に入れたような舌の異 和感が現われ, 千後には左口角部に運動麻痷が生じ た。

翌朝, 某院外科を受診。待ち時間の間に 左顔面全体に運動麻疸が広がった。特発性顔面神経 麻痷と診断され，頸部星状神経ブロックを受けた。 1 週 2 回, 計 8 回の神経ブロックを施行されたが無 効。次いで神経内科を紹介されプレドニソロン $20 \mathrm{mg}$ /日とニコチン酸 $\alpha$ ートコフェロールの投与を受けた が, 1 力月を経過しても何らの改善は得られず中止。 マッサージ治療のみを受けていたが知人の紹介で当 部を受診した。

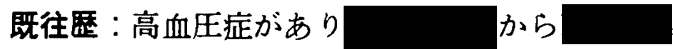
まで降圧剤を服用していた。

来院時現症：身長 $173.4 \mathrm{~cm}$, 体重 $77 \mathrm{~kg}$ 。体温 36.8 $C$, 血圧 $140 \sim 88 \mathrm{~mm} \mathrm{Hg}$, 脈拍 62/分, 整。やや赤ら 顔で小肥りの体軀である。

顔面神経麻疩は左側の末梢型で, 軽度の味覚異常 を伴らがフブミ骨筋の障害は伴わない。他の脳神経 症状, 錐体路障害, 知覚障害は認めない。身体的所 見にも特記すべきものはない。

漠方医学的所見 ..小肥りで赤ら顔, 上熱下寒の傾 向があり，身体上部に自汗をみる。口渴汢無い。気 分がすぐれず，イライラする。睡眠は良好。食欲普 通。大便 1 日 1 回, 小便の回数は日中 $7 \sim 8$ 回, 夜 間 1 回。関節症状，皮虐症状等は伴わない。電気毛 布を冬に常用。

脈は左右とも沈細でわずかに緊状あり。舌は腫大 し, 湿潤した白黄苔が中等度みられる。色調は暗柴 調であるが淡白紅ではない。

腹候: 腹力は中等度よりやや実し, 心下㾂鞕と右 側の胸脇苦満がある。この他, 右腹直筇の軽度緊張 と両側臍傍に圧痛を認める。柴胡剤を用いるとすれ ば大柴胡去大黄あたりの向く所見である。

しかし電気温鍼法を小倉法5)で施行したところ， $2 \mathrm{nd}$ 強度で 30 分間の負荷に耐え, 終了後はすこぶ る快適たといら。

模查成綪：血算, 血液生化学検查, 血清学的検査, 尿検査所見に異常はない。

治痖方針と経過：病症は明らかに風に侵された結 果であり, 主座は表にある。内熱の候は無く, 脈沈
緊，電気温鍼時間は少陰病を示唆する。頻尿も少陰 の指示材料である。舌腫大, 心下㾂鞕は痰飲の併存 も思わせる。先表後裏で, まず表の風寒湿を去るべ きと考え小続命湯（炮附子 $1.0 \mathrm{~g}$ ）を採用した。

2 週間後再診。左奥唇溝の辺りがわずかに動くよ うになり, 左顔面の腫れた感じが減少した。夜間尿 は無くなり, 日中も小便 4一5 回となる。炮附子 $2.0 \mathrm{~g}$ に増量。

4 週間後再診。口角から水のこぼれる症状が無く なり，眼䀫も大分閉じられるよらになった。

3 力月後, ほぼ正常に復したが, 左眼䀫部の異和 感がわずかに残る。桂枝茯苓丸（ウチダ）1日6gを 併用することとし，同年—，4週間分を処方 し, 廃薬とした。

\section{症例 $2 ： 35$ 才, 主婦（口。}

肩から上腕にか沙ての疼痛, 腰から大腿外側の疼 痛, 後頭部痛を主訴以来院。

現病楚 : 頃上り腰痛を自覚。翌年 頃から項部, 背部が脊柱に沿ってチクチク、ヒリヒ リと痛むようになった。後頭部痛も出現。

同年頃より両側の肩のつけ根から両上腕にか けて芯がウズくようになった。

に至り，気温の低い甘が多くなると同時に諸 症状は一段と増悪したため米院した。

身体痛は朝方とくにひどく，一日中続く。また疼 痛部位は日によって，また一日のうちでも移動する 傾向がある。入浴により改善。

既往歴 : , 尿路感染症。

家族歴：母に胃潰瘍の既往。両親・夫とも健在。 夫と女児 2 人の計 4 人家族である。

来院時現症: 身長 $154 \mathrm{~cm}$, 体重 $49 \mathrm{~kg}$, 血圧 100 一 $56 \mathrm{~mm} \mathrm{Hg}$, 体温 $37.4^{\circ} \mathrm{C}$, 脈拍 $58 /$ 分, 整。貧血, 黄疸 等はなく，胸腹部の身体所見には特記すべきことは ない。

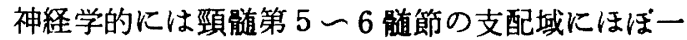
致して両側上肢に軽度の痛覚過敏が存在するが, 筋 力低下・筋萎縮等は伴わない。脳神経領域にも異常 を認めない。下肢の筋力, 表在知覚, 深部反射はい ずれも正常。

足背動脈は明瞭に触知する。レイノ一現象はなく 皮扂の硬化, 発斑も無い。 
漠方医学的所見：中肉中背で色白である。眼光に カがなく，抑らつ的な印象を受ける。

大便は秘結し 2 - 3 日に 1 度の硬便。小便は正常。 自覚的には気力が無く, 些細なことが気になり, 怒 り易い。食欲は普通。眠りは浅くよく夢を見る。肩 や首筋の凝り, 後頭部痛がある。月経は順調たが生 理血に血塊がある。

平素から寒がりで, 使用している。

脈は細弱でやや沈。舌は腫大し，淡白紅。湿潤し た微白荅に全面が被れている。

腹候：腹力は軟弱で, 心下㾂鞕, 軽度の胸脇苦満,

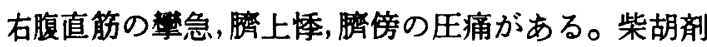
を用いるとすれば柴胡桂枝乾姜湯の向く所である。

小倉法による電気温銊は 2 nd の強度で 30 分以上 である。

模查成绪：血算, 血液生化学検査, 血清学的検査, 尿検查にはいずれも異常所見を認めない。筋電田， 骨レントゲン写真(頸椎,腰椎)にも異常所見がない。

治凊方針と程遗：本症に西洋医学的な病名を与え るとすれば不定愁訴症候群であろう。脊髄根障害と しては根拠に乏しい。末梢神経栄着血管系の循環不 全も推測されるが証明は難しい。

漢方的には疼痛が非固定性であることから病症は 未だ経絡にあり，表を主座としていると考えられる。 冬期に発症し，冬を迎えて悪化するのは，電気温銊 の耐久時間とも併せて寒の関与を示唆する。舌候と 心下㾂䩿は痰飲の併存も思わせる。桂附の向く証と 考之，小続命湯(附子 $1.0 \mathrm{~g}$ )を試用することとした。

2 週間後再診。背筋のヒリヒリ感が半減。電気温 鋮時間30分。炮附子を $2.0 \mathrm{~g}$ 亿增量。

4 週間後再診。上肢・下肢のウズくような疼痛が わずかに軽快。後頭部痛が半减。抑らつ的な傾向が 改善してきた。炮附子 $2.5 \mathrm{~g}$ に増量。電気温鐵時間 2 ndで21分。

6 週間後再診, 諸症状半減。電気温鋮時間15分に 短縮。

4 力月後, 立春を迎えた頃より諸症状は著しく改 善し, 以後, 自らの判断で来院しなくなっ た。

本報告を行らため，
たところ，その後はすこぶる順調に経過していると いう。

症例 $3: 52$ 才, 女性, 調理師 左眼䀫痙攀を主訴に初診。

現病歴：5ー6 年前より, 原因と思われることな しに左眼䀫瘃攣出現。近医にて, 乳突孔 (Foramen mastoideum) 部での顔面神経 ブロックを 4 回受け た。各々 3 力月間位は有効であるが再発をくり返し ている。

某院脳外科より, microvascular decompression を勧められたが，手術前に漢方治療を試みたいとい ら患者の希望で紹介され来院。

痙攣の起こる部位は左頓部が主で, 眼䀫に及ぶが, 左口角部に波及することもある。左耳の奥でカサカ サーガサガサ音がするような日には痙摮が激しいと いら。朝タで症状は変化しない。

既往歷, 家族歴に特記すべきことはない。

来院時現症: 身長 $144 \mathrm{~cm}$, 体重 $49 \mathrm{~kg}$, 体温 $35.8^{\circ} \mathrm{C}$, 血压114 - 78 $\mathrm{mm} \mathrm{Hg}$, 脈拍68/分, 心音, 呼吸音, 腹部 触診等の身体所見に特記すべきものはない。

神経学的にも, 左顔面の煩部・眼瞼 部の筋痙攀 （spasm）の他には脳神経系に異常なく, 錐体路, 錐体外路症候, 知覚障害をみとめない。

漠方医学的所見: 大便, 小便, 食欲, 睡眠に異常 はない。自汗の傾向はない。腰から下が冷え, 冬に は電気毛布を必要とする。首の凝りがあり, 時に後 頭部を主に頭痛が起こるが，この頭痛は月経前に現 われる傾向にある。カサカサといら耳鳴りが時にみ られ, 羞明感がある。しばしば年汁, くしゃみが出 る。

朝, 歯をみがくときにムカッキがあり, 排ガスも 多い。皮庙症状はない。月経は順調。

脈は弦弱。舌は腫大歯痕舌で, 正常な赤味があり, 無苔。

腹候：腹力は中等度。軽度の心下㾂鞕と明らかな 右胸脇苦満がある。臍傍の圧痛と抵抗を示す部位は 一塊となり，馬蹄形をなしている。臍上悸, 胃部振 水音はない。

顔面頓部は軽度に紅潮しているが，四肢末梢には 冷えがある。下肢に浮腫はない。

治丵方針と释過：脳外科的に脳幹部一到達し，顔 
面神経を王迫する血管を引き戻す， microvascular decompression む相当に有効性が高く, 比較的安全 に施行されている。またこの手術に際して，料台に 接した脳腫境が明らかになることがある。しかし麻 酔に伴う事故，術中に聴神経等を損傷したり，錐体 路障害, 脳幹障害を来すことも皆無ではない。そこ で著者らは, 脳幹部 C Tスキャン, 内耳孔撮影など により病態を把握し, 一定の期間, 漢方的にアプロ 一チし，無効な場合に手術を勧めるよらにしている。

本症も風に侵された病態と考えることができる。 その主たる病変は顔面に限られており, クシャミ,

水などの炎症候, 頭痛などのいわゆる外候を示 していることから，一部に半表半裏の症候を伴うも ののその主座は表にあるものと考えた。

腰冷を自覚し, 四肢厥冷のあることから寒の関与 も示唆され, 舌の腫大, 心下㾂鞕は痰飲の併存も示 している。

小続命湯（炮附子1.0g）を投与することとした。

2 週間後再診。血圧 $124 \sim 76 \mathrm{~mm} \mathrm{Hg}, 36.8 \mathrm{C}$ 。14日 間のらち 7 日間程度よい日があった。眼瞼座攀の内 容に変化が起こり, 小キザミに襲ら㢣縮がなくなっ たといら。

4 週間, 6 週間, 8 週間目の再診はほぼ同様症状 のまま経過。

10週間経過した頃から耳の奥のカサカサいう耳鳴 りが消失。腹候も胸脇苦満が消失し, 臍傍の圧痛と, 軽度の心下㾂鞕を残すのみとなった。9カ月の服薬 で廃薬。本報告を行らため廃薬後 1 年の経過を問い 合せたところ順調に経過しているとの返事を得た。

症例 4 : 71才, 男性 D。

左上肢の芯のウズくよらな痛みを主訴に , 受診。

現病暦：3 年前より初冬になると左上肢痛が出 現。春先まで痛みが続く。近医（整形外科）で消炎 剂, 筋弛緩剤を投与され，頸椎率引療法を行ったとこ ろ,一時は軽快したが, 本年も迎えると同時に 再び疼痛が出現したため漢方治療を希望して来院。

既往厢：頸椎の打撲，ムチ打ち症等の既往はない。

家族原：特記すべきことはない。

来院時現症: 身長 $169 \mathrm{~cm}$, 体重 $68 \mathrm{~kg}$ 。体温 $36.3 \mathrm{C}$, 血圧 $168 \sim 94 \mathrm{~mm} \mathrm{Hg}$ ，脈拍 $60 /$ 分。
神経学的には影艏第 6 噵節の支配域に一致して全 知覚低下が軽度にあり, 筋力は左三角筋, 左側の手 関節伸筋群に軽度の筋力低下がある。筋萎縮は伴わ ない。

深部反射は上肢, 下肢ともに areflexia で足底反 射は底屈。氫性はなく, myelopathy の合併所見は ない。

他の身体所見では心濁音界がやや払大しているの みで, 特記すべきものがない。

漠方医学的所見：比較的大きな体䐸で, 顔面は赤 味があり，頓部には細絡が目立つ。

大便, 小便は正常で, 食欲も良好, 睡眠障害なし。 口乾がある。肩こり,くしゃみ，皮庙の枯燥感があ る。頭痛はない。冬には電気毛布を常用, また入浴 すると疼痛は軽減する。

脈は硬く, 実状があり, やや沈。

舌は暗赤色で, 湿潤した白黄苔に被れている。腹 候では腹力は充実し, 心下㾂鞕と軽度の右側胸脇苦

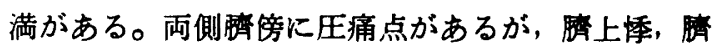
下不化，胃部振水音はいずれも認めない。

检查所見：頸惟レントゲン撮影では頸惟の変形が 著しく, とくに C6/7 惟间孔仕左側で狭少化してい る。

胸部レントゲン撮影では肺野に異常はないが，左 室成分が拡大し，心胸郭比 $57 \%$ と增加。

血算, 血液生化学検査, 血清学的検查, 尿検査に はいずれも異常を認めない。

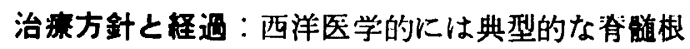
障害である。これに伴って障害部の虚血, 浮腫が病 像を形成しているものと考えられる。手術適応もあ る症例であるが, 夏季には症状が著しく改善するこ とから, 血流障害の要素が比較的大きく関与してい るものと考光, 数力月漢方治療により加療すること を試みることにした。小続命湯（炮附子 $1.0 \mathrm{~g}$ ) 投 与。

2 週間後再診。血压170 - $100 \mathrm{~mm} \mathrm{Hg}$, 体温 $35.8 \mathrm{C}$ ， 芯のウズくような痛みは著しく軽減。早朝洗顔時に 左局甲部に激痛が走るとい5。炮附子を $2.0 \mathrm{~g}$ に增 量。

4 週間後, 再診。疼痛は全く消失し, 知覚障害も 改善。左三角筋の筋力低下は不变。 
8 週間後, 諸症状ほぼ正常に復す。

症例 5 :34才, 男性, 工員 D。

右前脛骨筋麻疩，右側腹部および右下肢の耐之難 、疼痛を主訴に一来院。

現歴: 10年前, 腰痛が出現, 整形外科病院で椎 間板ヘルニアと診断され, 療法を受け1力月で 柽快, しかしその後も腰痛は出没した。

$3 ー 4$ 年前より物につまづき易くなり，右足首の 背屈ができにくくなった。某院整形外科で再び腰椎 々間板障害と診断され，斢引療法を受けたが，両下 肢の知覚障害も出現。

上り排尿障害が出現, このころ左下肢 の知覚障害は俥快した。

同年—当院整形外科を受診。当部を稆介された。 排尿障害は軽块。

来院時現症：身長 $165 \mathrm{~cm}$, 体重 $69 \mathrm{~kg}$ 。血圧 108 - 74

$\mathrm{m} \mathrm{Hg}$, 脈拍 $60 /$ 分, 整。体温 $36.2 \mathrm{C}$ 。

神経学的には脳神経領城に異常なく, 上肢にも知 覚障害, 運動障害はない。

右下肢の前脛骨筋の筋力が著しく低下 (3/5) し， このため尖足位をとる。

知覚鈍麻が右腹部の胸铕第 8 レベルから鼠径部の 腰椎第 1 レベルにあり, 右下肢大腿外側から㮏関節 上悢および右前脛骨部上半にも地図状の全知覚低下 がみられる。

深部反射は上下肢とも正常で，バビンスキー反射 等の病的反射はない。膀胱直晹障害も伴わない。

すなわち, 䒃内病変よりは多巣性の末梢神経障害 を示唆する所見である。

黄疸, 貧血症状, 甲状腺腫はなく, 胸腹部の打聴 診, 触診では特記すべき異常はない。

港方医学的所見：中肉，小肥りで浅黒い皮庙であ る。上熱下寒の傾向があり，首から上に汗をかき易 い。疲れ易く, 翌朝疲れが残る。大便，小便に異常 なく, 食欲も正常。手足が冷え, 冬には電気毛布が

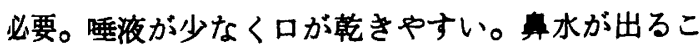
とがあり, 口苦, 嗳気がある。朝, 手のこわばるこ ともある。

脈は沈弱。舌は腫大歯痕舌で，湿潤した微白苔を 被る。腹候は腹力充実し, 軽度の心下㾂绠と右胸脇 苦満, 左胍傍圧痛がある。柴胡剤であれば大柴胡湯
の向く所見である。

模至所見：頭部CTスキャン，ミエログラフィー には異常所見なし。メトリザマイドを用いた脊能 C Tスキャンにおいても脊随空洞症の所見はない。筋 電困では左・右の大腿四頭筋に神経原性変化, 右前 脛骨筋は電位が得られない。

血算, 血液生化学, 血清学的検査, 尿検査所見に 異常はない。

治嫁方針と程週: 初診時, 腹候から, 大柴胡湯合 桂枝获荅丸料を投与。 4 力月間本方で経過を観察。 右下肢の疼痛と腰痛は全体の 2 割程度改善した。し かし前脛骨筋の麻瘃は不变で, 疼痛も激しく, やむ を得ずカルバマビピンを併用した。

ここで，電気温鍼法を施行したところ 2 ndの強度 で30分以上耐久し，しかも温鋮後に痛みが著しく軽 隇したことから寒証と考え, しかも病症は表を主座 としていることから小続命湯（炮附子1.0g）に転じ た。

2 週間後, 大腿部の疼痛とシビレ感が $20 \%$ 程度减 少。炮附子 $1.0 \mathrm{~g}$ に鳥頭 $1.0 \mathrm{~g}$, 茩术 $3.0 \mathrm{~g}$ 追加。

4 週間後, カルバマゼピンの頓用は不要となる。

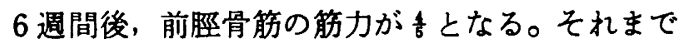
常用していた短装具なしで步行可能。

3 力月後, 諸症状は著しく改善, 復職した。約 2 年後の現在, ほとんど障害なく, 鉄工所の工員とし て就労している。

\section{附圮}

以上の 5 症例に加えて，小続命湯が有効であったと考 えられる症例には，20年の経過を有する筋緊張 性 頭痛 （50才，男性, , 発症後 7 力月を経過した脳 血栓症による右片麻㽻と失語症（69才，女性，

), 脳血柽症の後遭症として後頭部痡を訴える症例(69 才，男性， D, 非定型性顔面痛の一例(61才， 女性, — ), 脳出血後遣症の一例 (70才，男性,

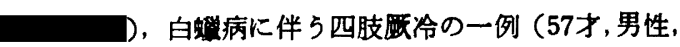
D，そして馬尾神経障害の一例（56才，男性， (がある。

\section{考按}

千金方1)巻八・諸風門の「論雑風状第一」には「夫 
眼閏動口需動偏喎。皆風入脉。故須急服小続命湯。」 と記されており, 眼瞼痤杽あるいは顔面神経麻疸と 推定される病態は風が脉に入ったのであるから早急 に小続命湯で対処せよと指示している。症例 1 と症 例 3 はこの例である。

症例 2 は身体痛であるが, 後頭部痛も主訴に加わ っている。われわれはこれまでに筋緊張性頭痛で諸 治に応じなった症例と, 脳血栓症の後遺症として みられた頭痛について，小綕命湯で良好な結果を得 た。小続命湯之頭痛について森立之は『蘭軒医談』(6) の中に「小続命湯は東垣の升陽散火湯と同意にて, 至て小手の利く方なり, 頭痛の凉膈茶調の類を用て 効なきに用て奇効あり、これ栄衛の凝滞を通達する の神剤なればなり……」記している。

香月牛山は『牛山方考』 2) に, 小続命湯が諸種の 疼痛, 麻痷に奇効のあることを「婦人産後腰足冷腹 痛甚く㮏屈て伸びざる症に小続命湯に木瓜, 萻药仡 を加えて奇効あり。」また「老人血虚の脚気に小続 命湯に木瓜, 海桐皮を加て奇効あり。」と記してい る。ただし牛山の記す小続命湯は古今 録験 続 命湯 （金鄫続命湯）に防風, 肉桂, 苟薬, 附子, 防已を 加えたもので千金方の小続命湯とは若干異なってい る。

小続命湯は越婢加术湯を祖方とするとも言われる が6)，風寒湿を去りながら正気を扶ける方意である。
千金方の主治の末尾に「不令人虚」とあるがまこと に巧みな配剤である。

\section{結 語}

小続命湯の奏効したと考えられる代表的な 5 症例 を報告した。本方は風寒湿を去り正気を扶ける方意 であり，広い応用範用を有する方剤と考える。

期辞 本稿の考察に当り, 藤平健, 福田佳弘両氏より贵 重な助言をいただいた。記して謝意を表する。

\section{文埱}

1）係思选：備急千金要方(印彰復刻版), 自由出版社. 中華民国台北市，1976年

2）香月牛山：牛山方考、大塚敬節・矢数道明編，漢方 医学書集成(61)，名著出版，東京，1981，p. 149-150

3）浅田宗伯：勿語薬室函口訣（印彰复刻版）, 燎原書 店, 東京, 1975年, p. 284-285

4）大塚敬節：症候による漢方治療の実際, 南山堂, 東 京, 1963, p. 637-638

5）小倉重成：傷寒論による漢方と鍼食の統合診療，㓣 元社, 大阪, 1983. p. 23-27

6）森立之：蔽軒医談（印影復刻版）, 盛文堂, 東京 1974，25葉

（1986年 1 月22日受付） 